\title{
Gender Roles in Cuba: Leaving the Kitchen Isn't Enough
}

\author{
Ania Terrero
}

Excerpted and translated from the Spanish (Letras de Género, CUBADEBATE) and reprinted with the author's permission.

Original available at: http://www.cubadebate.cu/especiales/2020/01/23/roles-de-genero-y-si-no-basta-con-salir-de-la-cocina/\#.XioBOSO23IU

The scene: a family doctor-and-nurse office. After the usual wellbaby visit for the eight-month-old, the physician poses a question to the young mother that sounds more like a statement: "I suppose you won't be going back to work, right? You'll be staying home to take care of your little girl."

The mother, surprised, responds with a laugh: "Of course not. As soon as she's a year old and walking, she'll be going to day care and l'll be going back to work." The doctor, a look of concern crossing her brow, responds: "But once they start in day care, they catch all kinds of things. They're much safer at home." The mother, now unsmiling, says: "Well, she'll just have to catch antibodies." Attempting a joke, the specialist sighs: "Ah, my friend... and you've been such a good mother!" Silence. How do you respond to this? Two truths are implicit in the commentary, thought the young mother. The first, that the doctor wasn't sure at the outset that she was a good mother. And the other, that once she decides to send her daughter to day care, she stops being one.

Apparently to be a good mother, you have to stay at home. As if there was only one model for motherhood. As if-once again-the father was expected to provide for his children and the mother to raise them. This is a true story, one that hits close to home, from right here in Cuba. And it says a lot.

When Aníbal was little, he played with dolls. This worried the day care teachers, who sent for his mother. "The boy gets here and starts playing house with the girls. Maybe he needs to see a psychologist," they tell her. My mother, flabbergasted, responds: "So why is there a problem? He's used to playing the father to his sisters' dolls."

My brother had cars, whole parking lots, robots, construction tools, even a spinning top... and he loved them all. But with my sister Amanda and me, his main allies come playtime, he had few options. So some days he played the dad in our doll houses and others, he organized the car races. When he entered nursery school, he reproduced these behaviors. He never understood, and in fact never knew, that boys and girls were supposed to play different games. He didn't need that. He was just happy.

Gender roles are assigned to people depending on their sex at birth and, over time, influence the ways established for men and women to act in society. They are transmitted and acquired almost unconsciously through family, teachers, mass media and other avenues. They start with blue for boys and pink for girls, but continue through every stage of personal development.

A couple of years ago, a "compliment" got me thinking. A young guy told me that I was so pretty that he'd take me home with him, so I could also make his house pretty, and thus never have to leave or be bothered by working. In addition to the implicit harassment, I was irritated by the essence of his comment. For him, my place was not out in the world but rather taking care of and adorning his house. And moreover, this should be considered a privilege for me!

Recently, since l've become a mother, more than once walking with my daughter, men have shouted at me things like this: "Don't worry darling, your daughter will always have a daddy to provide for her with a mommy like you!." I know some will say that both kinds of comments have been heard forever, that they're part of "Cubans' witty cultural traditions," an "essential part of our idiosyncrasy."

But besides being examples of harassment, behind them lay the sexist distribution of roles that has accompanied humanity for centuries. Hear this: we women are supposed to be homemakers, to give pride and satisfaction to men, be an asset to their image. And they, in turn, will provide for us and our children.

The worst thing is that we've spent years trying to get rid of these stereotypes [in Cuba] and, after enormous effort, have only made a dent. Those who preceded us managed to get out of the kitchen, began to conquer the world, graduated in science and engineering, gained access to professions historically reserved for men, and reached leadership in politics and in public spaces. You just have to review the statistics to see that women are virtually everywhere. They're in parliament, in Popular Power assemblies at all levels, in research centers, on the bench, in universities, in mass media. In some arenas, they're even the majority.

However, while women leave the house to join the workforce, few men share the work back home. The result: women do a double shift, working outside the home by day and inside by night. Almost always, they have to combine traditional roles as mothers and homemakers with their new professional conquests. In some more advanced scenarios where men have begun to share household work, women still organize family routines. In feminist theory, this is called the "mental burden", that is, when men expect women to assign them household tasks, unconsciously assuming that women are the only ones who understand what, when and how things should get done.

The problem is that when women become organizers, and at the same time carry out part of the chores, in reality they're doing three fourths of the work. They have to be aware of everything and remember everything. And it's work that they generally carry out by themselves, added to all their other responsibilities....invisible, exhausting.

Since my daughter Ainoa arrived, many people have told me that motherhood is now the most important thing in my life, that everything else is secondary and that I should make sacrifices so as to raise her well. In a certain sense, this is true. The problem is that very few people demand the same level of sacrifice from fathers. Yet, motherhood doesn't necessarily mean renouncing everything else when it's accompanied by responsible fatherhood. 


\section{Viewpoint}

When children come along, often gender roles become even more polarized. In Cuba, with parental leave guaranteed for the first year after birth, most postpartum mothers stay at home, sleepless, learning how to care for their babies. The fathers almost always stay at work to bring in more income. Influenced by factors such as breastfeeding and the recuperation needed in the postpartum period, the pattern is repeated unconsciously: mom as caretaker, dad as provider. At least during the first year. In fact, although paternity leave is possible under Cuban law, few men take it.

Everything becomes more complicated when women return to work. At that point, they have to combine the demands of their jobs with those of their households, adding attention to their children, often with little to no participation by their male partners.

But what happens when a father assumes an active role in childrearing and household responsibilities, when tasks are shared equitably? In such cases, men sometimes suffer discrimination from a society not accustomed to finding them in these roles. When fathers are kept from an active role in birthing, when physicians openly ignore them in their offices, when they arrive at hospital with their children and are asked where the mother is, when people are surprised to see them walking alone with their babies, when no media reflect them caring for their children...then, time and again, they are excluded from the whole process. Society is showing them that they aren't part of these activities, that they have no business doing them. And if men aren't taught differently, then later it's very difficult to demand that they act differently.

Our culture, mass media and society show women in their roles as wives and mothers and men as workers or professionals. So we return, then, to the vicious cycle of pink and blue, of those who feel and those who don't cry, those who change diapers and those who bring home the bacon. It's not enough that women have left the kitchen and every day conquer a bit more of the outside world. We have to break the chain, discard the stereotypes, transcend the most arcane versions of our roles and shed their most hidden manifestations.

We need more media reflecting equitable roles, more families that share in all the tasks, more women in all public spaces, more fathers who take paternity leave, more boys who play with dolls, and fewer doctors who think being a good mother means staying at home. -1 -

Correspondence: aterrero95@gmail.com 